\title{
THE POTENTIAL FINANCIAL UPLIFTMENT OF INNER-CITY STREET TRADERS THROUGH THE PROVISION OF RENTAL STANDS
}

\author{
Chris Callaghan* \\ University of the Witwatersrand \\ Chris.callaghan@wits.ac.za \\ Tendai Gwatidzo" \\ University of the Witwatersrand \\ Tendai.gwatidzo@wits.ac.za
}

Received: September 2012

Accepted: October 2013

\begin{abstract}
Historically, policy applied to the informal sector in the Southern African context has been either (i) 'restrictive', or aimed at the elimination or eradication of the sector; or has been (ii) 'promotive', or aimed at the financial upliftment of certain informal participants in order to enable the potential for economic developmental inherent in the sector. This research provides evidence of the financial impact of one such 'promotive' intervention: the provision of street-trader rental stands by local government. Using survey data from 2008, 2009, and 2010, an exploratory parametric research design is applied, using t-tests, Pearson point biserial tests, partial correlation analysis, chi-squared tests and multiple linear regression. Results suggest that the provision of rental stands can (i) significantly reduce gender inequality in earnings; enable traders (ii) to work more hours a day; (iii) to offer more capital-intensive product offerings; and (iv) to obtain higher gross daily earnings.
\end{abstract}

Keywords

Financial development, informal sector, public policy, street trading.

*Dr Chris W Callaghan is a lecturer at the School of Economic and Business Sciences, University of the Witwatersrand, Johannesburg, South Africa.

\#Dr Tendai Gwatidzo is a senior lecturer at the School of Economic and Business Sciences, University of the Witwatersrand, Johannesburg, South Africa. 


\section{INTRODUCTION}

As a consequence of the surge in post-apartheid South Africa's urban population, which has been influenced by increasing rural-urban migration and large inflows of immigrants from other countries (Rogerson, 1996; Crush, 1999; Peberdy \& Rogerson, 2003; Landau, 2007; Adcorp, $2012 b$ ), the ranks of the country's informal sector have burgeoned. Given its low barriers to entry, the informal sector has seen significant inflows into its ranks commensurate with these increasing levels of migration and immigration, both legal and illegal (Rogerson, 1996; ILO, 2002). Given such high rates of urbanisation, the numbers of street traders are expected to expand (Skinner, 2008), particularly in a context of relatively high unemployment in the formal sector of the economy (Schoeman, Botha \& Blaauw, 2010). The informal sector currently employs about $32.8 \%$ of the potential workforce (about 6.2 million people), in contrast to the formal sector, which employs about 12.7 million people (Adcorp, 2012a). Research into the informal sector is therefore considered to be increasingly important. The sector, therefore, clearly has a substantial role to play in employment creation (Ligthelm, 2006; Rogerson, 1996). What is not as clear, however, is the role of the sector in the enterprise-related development of people within the sector, and the specific role of the state in such potential development. This article seeks to test, and provide empirical evidence of, the financial impact of one such 'pro-enterprise' state intervention in the informal sector: the provision of rental trading stands to street traders.

The informal sector is defined here as generally unregulated and unregistered activities that typically fall outside the formal regulated sector of the economy (Devey, Skinner \& Velodia, 2006). Despite much contemporary literature on the informal sector (Celik, 2011; Raveendran, 2011; Sinha \& Roever, 2011; Streetnet International, 2011; Van Rooyen \& Antonites, 2007), there is no literature that specifically tests the financial impact of the provision of street trading stands to informal sector participants. It is suggested in this article that without clear tests of the impact of such interventions, the influence of supportive, or 'promotive', state policies in the informal sector cannot be known.

The role of the state in the informal sector has typically been one of (i) 'restrictive' policy, in which the sector has been viewed as a problem to be eradicated or reduced, or of (ii) 'promotive' policy, where the role of the sector in economic upliftment is recognised and enabled by local governments (ILO, 2002). Different theoretical perspectives offer different predictions in this regard. These different theoretical perspectives are now considered.

\section{MARGINALIST PERSPECTIVES}

Structuralist theory argues that people who join the informal sector are victims of the global capitalist economic system, a by-product of capitalism (Williams \& Round, 2010). Similarly, the sector has been conceptualised as a pool of 'reserve labour' for exploitative capitalist structures, which essentially has no developmental role (Wellings \& Sutcliffe, 2004). Further, Marxist theory also does not ascribe a developmental role for the sector (Meagher, 1995). The informal sector has been pejoratively described by some as 'backward', 'underdeveloped', 'parasitic', 'marginal' and a 'vestige of a disappearing past' (Williams \& Round, 2010: 393; Cross, 2000). These perspectives of the informal sector can be taken to represent the 'marginalist' view of the sector, and have typically been associated with a 'restrictive' approach to policy in the sector. In the Southern African regional context, numerous examples exist of instances where 'restrictive' policies have been applied. These 'restrictive', or punitive, approaches applied in 
the region have typically viewed informal trading as a nuisance, or as a criminal activity which must be eliminated (Nykya, 2006; Tibaijuka, 2005). In the 1980s in Tanzania the self-employed were considered 'unproductive, idle and disorderly' (Nukya, 2006). Violent evictions of street traders ensued (Nykya, 2006). The main reason for resentment is that the informal sector is associated with tax evasion in most developing countries (Shende, 2002). There was a massive eviction of street traders in 2005 in Zimbabwe that resulted in the physical destruction of business properties owned by informal traders (Tibaijuka, 2005). The policy that marginalised the informal traders in Zimbabwe was referred to as Operation Murambatsvina (translated as: 'getting rid of the filth') and affected $20 \%$ of the population (Tibaijuka, 2005). Restrictive policies also pose significant constraints to economic and entrepreneurial upliftment that derive from the over-regulation of enterprise (De Soto, 2000). The marginalist perspectives, however, are challenged by theorists who focus on a promotive stance towards the informal sector and informal sector development policies. The entrepreneurial perspective to economic development views the informal sector positively.

\section{ENTREPRENEURIALIST PERSPECTIVES}

In contrast to the perspectives of marginalist theory, other theories suggest that a 'promotive' policy approach to the informal sector might be more appropriate. Human Capital Theory (Becker, 1964) argues that context-specific learning, or Specific Human Capital, is typically associated with productivity improvements over time. Such productivity improvements typically enable higher levels of earnings across contexts (Becker, 1964). According to seminal theorists such as De Soto (1989), the informal sector has an important role as a 'training ground' for entrepreneurs. Such entrepreneurs can emerge from the sector and grow their enterprises to become formalised (De Soto, 1989). These theoretical perspectives can be taken to represent the 'entrepreneurialist' view of the sector. The promotive stance essentially acknowledges the permanence of the informal sector and informal trading. It recognises the informal sector and its economic role and acknowledges its linkage and symbiotic relationship with the formal economy (Moser, 1987). To this end, the approach argues that the government should create an enabling environment for such informal traders (Steyn, 2011). Neo-liberal theory also suggests that certain participants voluntarily choose to enter the sector, as they seek autonomy and flexibility (Cross, 2000). One important implication of such neo-liberal theory is that the informal sector will continue to be found in both developed and less-developed economies (Cross, 2000). Informal traders can offer their goods and services at lower prices than formal businesses, which incur relatively higher operational cost; one part of the urban poor may be subsidising the existence of another section of the poor (Bhowmik, 2005; Cross, 2000). Rather than being ephemeral and a nuisance (something that will disappear once capitalism's inability to absorb the unemployed has been addressed), certain scholars have argued that the informal sector, including street trading, is here to stay and plays an important economic role (Steyn, 2011; Heintz \& Valodia, 2008; Simone, 2004). The informal sector becomes relatively more vibrant for youth employment when large industries face collapse in developing countries (Calves \& Schoumaker, 2004). When unsound economic policies are followed the informal sector can thrive as large businesses struggle (Calves \& Schoumaker, 2004).

There is therefore a tension between these two conflicting theoretical perspectives as to the developmental potential of the informal sector. This tension is important, because public policy is typically based on the results of research that supports either one side of this tension or the other. 
This research therefore seeks to investigate the influence of access to City Government-provided rental stands on informal trader gross earnings, working hours and a range of further dimensions of inequality such as differences by gender, education and capital accumulation. By providing empirical evidence of such differences in this context, it is argued that a 'promotive' stance by local government through the more extensive provision of rental stands might enable significant upliftment. In order to better frame the potential impact of such research, further insight is provided into the informal literature as follows.

The high level of unemployment, coupled with South Africa's jobless growth and the huge influx of immigrants in recent times, has been found to be associated with an exponential growth in the country's informal sector (Landau, 2007; Skinner, 2008). Although the urban economy has continued to grow, its absorptive capacity is far smaller than the rate of urban population growth, such that unemployment has continued to increase amidst economic growth, a phenomenon called jobless growth (Pollin, Epstein, Heintz \& Ndikumana, 2006). This is potentially problematic, especially given the argument by the ILO (2002) that the informal sector may serve as an incubator for more formal and dynamic businesses (IL0, 2002; Devey et al., 2006). Further, according to the entrepreneurship literature, South Africa has been found to score lowest in total entrepreneurship activity of all developing countries included in Global Entrepreneurship Monitor reports (Urban, 2006). It is in this context that the tension between 'promotive' and 'restrictive' policies dominates certain discourse relating to the management of the sector (ILO, 2002). Under increasing pressure, the City of Johannesburg (COJ) and the government are in a difficult policy position. It is not clear whether or not they should they embark on a 'punitive' or 'restrictive' legal framework or a more 'promotive' and inclusive approach when it comes to dealing with the informal economy, and particularly street traders.

\section{THE RESEARCH PROBLEM AND AIM OF THE RESEARCH}

The research problem addressed in this article is that, despite an abundance of literature that relates to street trading (Celik, 2011; Raveendran, 2011; Sinha, \& Roever, 2011; Streetnet International, 2011), absent from scholarly work is research that specifically investigates the associative structure of relationships around the operation of a rental stand in the South African inner-city street-trading context. This research seeks to address this deficiency in the literature. Evidence from this investigation is used to make an argument that is central to this article: that a 'promotive' state intervention that is supportive of enterprise in the sector may have the potential to provide upliftment to informal street traders.

The aim of this article is therefore to provide evidence in support of the argument that there may be financial benefits associated with providing rental stands to street traders. The overarching aim of this research is to contribute to the informal trading literature by providing knowledge that contributes to the upliftment of people in the informal sector. The objective of the research, therefore, is to test theory that relates the operation of rental stands to real dimensions of informal enterprise and informal sector outcomes such as earnings and satisfaction. 


\section{THE RESEARCH PUESTION}

Does the operation of a rental stand contribute to improved outcomes for informal traders in the inner-city street-trading sector?

In order to answer this research question, we conduct empirical testing on whether the experience of street traders is differentiated by the operation of rental stands in the inner-city street-trading context. It is argued that a better understanding of the impact of government intervention is important for a number of reasons. First, government resources, with high opportunity costs, are being used and stakeholders need to know if such resources are being efficiently utilised. Second, in order to be sure that the intervention is viable the costs of such an intervention need to be compared with the benefits. This research aims to provide evidence of the benefits of such an intervention to informal participants. Third, if there is a human cost associated with non-intervention then it would need to be quantified. At this point further literature is considered and hypotheses are derived as follows.

\section{THE DERIVATION OF HYPOTHESES}

It is argued that the legitimacy associated with the operation of a rental stand might offer a different experience of street trading for traders operating rental stands. Traders with rental stands might be able to efficiently store their stock. This might confer a financial advantage to such traders in terms of the time they have available for selling. They might be able to stock more goods if they do not have to move their stock each day. It is predicted that if stock is stored on the stand, traders will also have more free time available to sell their wares. Therefore Hypothesis a is proposed: A significant difference will be found in hours worked per day by rental stand operation. The size of a street trader's selling space is prescribed by the City of Johannesburg Metropolitan Municipality by-laws (City of Johannesburg, 2004). A street trader is legally obligated to "ensure that his or her property area of activity does not cover an area of a public road or public space that is greater in extent than six square meters (with a maximum length of three meters) or unless otherwise approved by the Council" (City of Johannesburg, 2004:5).

The capital intensity of a street trader's provision might conceivably be constrained by the prescribed size of a rental stand. In certain cases, pavement sales might offer a larger area for stock, which might yield an advantage, but at the cost of exposure to by-law infringement. However, to the extent that the operation of such a rental stand might be perceived to offer a street trader legitimacy, and enable the accumulation of capital, an individual entering this sector will be expected to prefer to operate a stand (if the trader was aware of significant advantages associated with such a choice). Therefore, to the extent that individuals with more access to resources on entry (reflected in higher levels of initial investment) into the sector would have more access to such a choice the following hypothesis is offered: Hypothesis $b$. There is a significant difference in initial investment by rental stand operation.

It is also expected that access to higher levels of education in the most impoverished areas is a function of resources: the resources to hold off on leaving school and obtaining a job. It is argued that the co-incidence of higher levels of education and access to higher levels of resources is an inherent factor that influences access to rental stands. Individuals with higher levels of education are expected to be more likely to be able to access rental stands. Similarly, 
individuals with higher levels of education are also expected to be more able to discern advantages associated with the operation of a rental stand and to eventually 'gravitate' towards this choice, to the extent that such differences are perceived. Therefore Hypothesis $c$ is derived: Levels of education are expected to differ significantly by rental stand operation.

The operation of a Council rental stand might be a factor that enables the accumulation of capital in that such a rental stand would allow a trader to operate without stock confiscations. Hence, Hypothesis $d$ is offered: Levels of earnings will differ significantly by rental stand operation. If real financial advantages were perceived to be associated with rental stand operation then it would be expected that over time traders would try to gain access to such rental stands. This conception is tested as Hypothesis e: there is no difference in time spent in the sector by rental stand operation.

To the extent that the operation of a rental stand offers a certain protection from exposure to by-law contravention and might therefore fundamentally differentiate the experience of street trading, street traders with rental stands are expected to be more satisfied with continuing in street trading than traders without rental stands. This notion is tested as Hypothesis $f$ : there is no difference in continuance satisfaction by rental stand operation. If younger traders with more resources enter the sector yet have spent less time in the sector it is not clear as to which effect is stronger in terms of its association with rental stand operation: access to rental stand operation through having more resources, or through having more years of exposure to the context. Hypothesis $g$ was therefore tested: there is no difference in age by rental stand operation.

The advantage of being in Johannesburg longer might translate into an advantage in time spent on waiting lists for rental stands. Hypothesis $h$ is therefore posed: there is no difference in years spent in Johannesburg by rental stand operation. The fundamental assumption that underpins notions that informal upliftment is possible (De Soto, 1989) is that a mechanism of informal upliftment through capital accumulation can exist in this sector (Callaghan, 2012a). One such possible mechanism or 'ladder' upwards in the sector is the graduation of traders from categories of product provision associated with lower levels of capital investment to those with higher levels of capital investment (Callaghan, 2012a). If the operation of a rental stand were to enable capital accumulation through legitimacy in this manner, then the operation of a rental stand will be expected to be associated with differences in the types of products sold. More specifically, the types of products sold would be expected to be associated with higher levels of capital intensity when contrasted with traders without access to rental stands. Hypothesis $i$ is therefore offered: there is no significant association between rental stand operation and the capital intensity of product provision.

Through the testing of these hypotheses, the fundamental thesis of this study was also tested: that the operation of a rental stand fundamentally differentiates the experience of street trading, and that access to such stands offers a substantive advantage to traders who have access to them. Consequently, it is argued that not having access to such a stand might be a fundamental constraint to the development and upliftment of such street traders, and that certain traders without access to such stands might be 'trapped' in a zone of constrained capital accumulation. The methodology applied this research is discussed as follows. 


\section{METHODOLOGY}

This research applies an exploratory associative research design. Issues relating to data collection and data analysis are discussed as follows.

\subsection{Data collection}

Three sets of data were used, from the 'Street Trader Upliftment Programme', a research programme undertaken across the years $2008(n=339), 2009(n=308)$ and $2010(n=303)$ that obtained extensive data on the inner-city street trading population. From three data sets, the variables of interest were used to investigate the relationships around rental-stand operation. The data collection followed a process whereby the inner city was differentiated from the more residential and industrial area adjacent to the inner city. Adjacent areas dominated by transport nodes were also excluded. The inner city therefore comprised an area of about 228 city blocks bounded by Plein, End, Farraday and Sauer streets. Using random selection, the individual traders on $10 \%$ of these blocks were counted, which resulted in an estimate of the population as being about 5000 . Due to the strict application of ethical principles, all refusals were unconditionally respected. Consequently, due to the relatively high levels of refusals, results are claimed on the basis of convenience sampling. A sample size calculation was applied to ascertain the power of the tests and the samples of about 300 respondents each were considered acceptable in terms of sample size.

\subsection{Data analysis}

Data was analysed using SPSS statistical software. Using data from 2008, 2009 and 2010, hypotheses $\mathrm{a}-\mathrm{g}$ were tested using bootstrapped t-tests of differences by means. Hypothesis $\mathrm{i}$ was tested using bootstrapped Pearson point biserial tests of association and partial correlation analysis. Hypothesis $\mathrm{h}$ was tested using chi-squared measures. An exploratory application of bootstrapped multiple linear regression analysis was also used for the purposes of further insight into the differences in the factors that predict higher levels of earnings for traders with rental stands versus those without rental stands. The bootstrapped models are reported in TABLES 2, 3 and 4. TABLE 1 reports the descriptive statistics for the sample. All the tables are in the appendix. In the bootstrapping process 1000 samples were used, with a $95 \%$ confidence interval level.

The Durbin-Watson statistics were checked for serial correlation, for values that differed from two. The condition indices were checked, as were the variance inflation factors and tolerance values for evidence of potential multicollinearity. The exploratory models were also run without bootstrapping in order to gain an understanding of the quality of the underlying data, and the assumptions associated with the use of multiple linear regression analysis were tested. The distribution of residuals for the dependent variable for both the models was considered to reflect a reasonable approximation of normality. The plots of the residuals by predicted values for the dependent variables were acceptable. Cook's distance, outlier and leverage diagnostics were checked. The quartile-quartile plots reflected reasonable linearity. The variance inflation factors and tolerance values were checked for evidence of multicollinearity. The models were judged to be acceptable. The following variables were included in the analysis. The way in which they were each measured is also outlined as follows. 
Hours worked per day, and days worked per week were measured as just that. Initial investment was measured as the money invested in the venture at the time of start-up. Total education was measured as total years of formal education in 2009 and 2010, and using a five-point scale in 2008. Earnings were measured as gross earnings per day. Time in the sector was measured as years spent in street trading. Continuance satisfaction was measured as satisfaction with continuing in street trading. This item was measured using Likert-type scale items.

The Cronbach alpha values for the 2010 data were .906, .742, and .939 for 2008, 2009 and 2010, respectively, using two items in 2008 and three items in 2009 and 2010. Age was measured in years. Years in Johannesburg were measured as years spent in Johannesburg. South African origin was measured as a dummy variable, with 1 coded for traders of South African origin and 0 coded for traders of foreign origin. This variable was labelled as "RSA origin". Gender was coded in a similar manner. These variables (except for days worked per week, which was left out to avoid multicollinearity because hours worked per day was already included) were included in the exploratory multiple linear regression analysis, together with another variable, termed 'order of capture', which was used as a measure of the order in which the surveys were administered. This variable was expected to pick up the differences in the structure of the city blocks surveyed. The inclusion of this variable was also expected to control for any variance introduced into the process that was related to the order in which the surveys were administered. According to the 2008 sample, $44 \%$ were found to be of South African origin and $57 \%$ were found to be male. According to the 2009 sample, $40 \%$ were found to be of South African origin and $67 \%$ were found to be male. Analysis of the 2010 sample indicated that $41 \%$ of the sample was of South African origin and that $62 \%$ of the sample was male.

\section{RESULTS AND DISCUSSION}

Null-hypothesis a. There is no difference in hours worked per day by rental stand operation.

Traders with rental stands were found to work significantly more hours than traders without rental stands in all three years, according to the bootstrapped $t$-test measures (TABLE 1 ).

TABLE 1: Results of the $t$-tests for differences in Hours Worked per day

\begin{tabular}{|c|c|c|c|c|c|}
\hline $\begin{array}{c}\text { Hours worked } \\
\text { perday }\end{array}$ & $\begin{array}{c}\text { Levene's test } \\
\text { Fvalue }\end{array}$ & t-value & $\begin{array}{c}\text { Bootstrapped } \\
\text { Significance } 95 \% \\
\text { confidence levels }\end{array}$ & $\begin{array}{c}\text { Mean for } \\
\text { traders } \\
\text { without rental } \\
\text { stands }\end{array}$ & $\begin{array}{l}\text { Mean for } \\
\text { traders with } \\
\text { rental stands }\end{array}$ \\
\hline 2008 & .38 & $-1.9^{\wedge}$ & $\begin{array}{l}\text { Lower }-.75 \\
\text { Upper .009* }\end{array}$ & 10 (per day) & 10.4 (per day) \\
\hline 2009 & 1.2 & $-2.6 *$ & $\begin{array}{l}\text { Lower - } 1.1 \\
\text { Upper -.12* }\end{array}$ & 10.2 (per day) & 10.8 (per day) \\
\hline 2010 & $4.5^{\star}$ & $-2.4^{\star}$ & $\begin{array}{l}\text { Lower - } 1.03 \\
\text { Upper -.12* }\end{array}$ & 10.5 (per day) & 11 (per day) \\
\hline
\end{tabular}

Source: Authors' analysis

Notes: ${ }^{\star} p<.05 ;{ }^{* \star} p<.01 ;{ }^{\star \star \star} p<.001 ; \hat{p}<.10$ 
To the extent that working more hours a day can offer a trader an opportunity to earn more, the operation of a rental stand might offer a trader a competitive advantage over other traders without rental stands.

\section{Null-hypothesis b. There is no difference in initial investment by rental stand operation.}

Individuals with relatively higher levels of initial investment are found to be significantly more likely to operate rental stands in all three years. Interestingly, the contribution of initial investment differs in its relative contribution to earnings over this three-year period. In 2008, 2009 and 2010 the influence of initial investment dominates the regression equations of all three models for traders with rental stands (TABLES 2, 3 and 4). However, for traders without rental stands, according to the standardised coefficients, Continuance Satisfaction, and not initial investment, dominates the regression equations in 2008 and 2009. This might indicate that a rental stand may 'shield' a trader from the influence of dissatisfaction or satisfaction on earnings. In 2010, however, initial investment is the dominant predictor of earnings once again. The significant associations between initial investment and the operation of a rental stand might suggest that individuals with more access to resources might be more able to take possession of a rental stand. Further research is suggested into the possibility of a 'secondary market' in the rentals of stands in the sector.

(In TABLES 2, 3 and 4, ${ }^{\star} p<.05 ;{ }^{* \star} p<.01 ;{ }^{* \star} p<.001$. Coefficient is before slash/standardised coefficient is after slash.)

TABLE 2: Multiple Linear Regression Results, 2010

\begin{tabular}{lccc}
\hline & Rental Stands & No rental stands & All Traders \\
\hline Constant & -43.75 & -55.18 & -51.3 \\
Order of Capture & $.779 / .202^{\star}$ & $.254 / .09$ & $.462 / .147^{\star \star \star}$ \\
Gender & $76.4 / .127$ & $79.4 / .147^{\star}$ & $75.58 / .133^{\star}$ \\
South African origin & $-104.58 /-.182^{\star}$ & $-88.02 /-.162^{\star}$ & $-93.634 / .133^{\star \star \star}$ \\
Initial investment & $.057 / .276^{\star}$ & $.062 / .269 \star \star \star$ & $.059 / .276^{\star}$ \\
Education & $.763 / .009$ & $12.8 / .172^{\star}$ & $8.1 / .103^{\wedge}$ \\
Experience & $11.22 / .179^{\wedge}$ & $4.56 / .081$ & $7.66 / .129 \star$ \\
Continuance satisfaction & $18.73 / .154^{\star}$ & $19.5 / .196^{\star \star \star}$ & $18.38 / .171^{\star \star \star}$ \\
Rental stand & - & - & $2.48 / .005$ \\
R squared & .226 & .239 & .219 \\
Adjusted R squared & .179 & .208 & .200 \\
Respondents $(n)$ & 123 & 179 & 302 \\
F-value & 4.804 & 7.676 & 11.79 \\
$p$-value & $p<.0001$ & $p<.0001$ & $p<.0001$ \\
\hline
\end{tabular}

Source: Authors' analysis

Notes: ${ }^{\star} p<.05 ;{ }^{*} p<.01 ; * \star \star p<.001 ; \hat{p}<.10$ 
Callaghan \& Gwatidzo

TABLE 3: Multiple Linear Regression Results, 2009

\begin{tabular}{|c|c|c|c|}
\hline & Rental Stands & No rental stands & All Traders \\
\hline Constant & $19.6 *$ & .814 & 7.62 \\
\hline Order of Capture & $-.022 /-.123$ & $-.012 /-.061$ & $-.015 /-.083$ \\
\hline Gender & $-2.85 /-.082$ & $-.037 / .001$ & $-1.47 /-.042$ \\
\hline South African origin & $5.48 / .167^{\wedge}$ & $6.12 / .183 *$ & $6.0 / .178 * *$ \\
\hline Initial investment & $1.06 / .404 * \star$ & $.672 / .256 \star \star$ & $.87 / .331 * \star$ \\
\hline Education & $-.255 /-.037$ & $.434 / .074$ & $.145 / .022$ \\
\hline Experience & $-.099 /-.038$ & $.523 / .166^{\wedge}$ & $.131 / .046$ \\
\hline Continuance satisfaction & $.662 / .127$ & $1.17 / .273 \star \star$ & $.99 / .204 * *$ \\
\hline Rental stand & - & - & $3.06 / .093$ \\
\hline R squared & .155 & .233 & .226 \\
\hline Adjusted R squared & .114 & .197 & .205 \\
\hline Respondents $(n)$ & 152 & 154 & 307 \\
\hline F-value & 3.79 & 6.38 & 10.92 \\
\hline$p$-value & $p<.0001$ & $p<.0001$ & $p<.0001$ \\
\hline
\end{tabular}

Source: Authors'analysis

Notes: $* p<.05 ; * \star p<.01 ; \star \star \star x<.001 ; \hat{p}<.10$

TABLE 4: Multiple Linear Regression Results, 2008

\begin{tabular}{lccc}
\hline & Rental Stands & No rentalstands & Al/ Traders \\
\hline Constant & $14.22^{\star}$ & $5.366^{\wedge}$ & $7.9 \star \star$ \\
Order of Capture & $-.014 /-.099$ & $-.018 /-.158^{\star}$ & $-.016 /-.129$ \\
Gender & $-.208 /-.008$ & $.052 / .002$ & $.308 / .013$ \\
South African origin & $-2.12 /-.08$ & $-.379 /-.017$ & $-.831 /-.034$ \\
Initial investment & $.55 / .254 \star \star$ & $.402 / .200 \star \star$ & $.462 / .229$ \\
Education & $-.441 /-.041$ & $1.41 / .148 *$ & $.777 / .077$ \\
Experience & $.191 / .047$ & $.295 / .079$ & $.231 / .059$ \\
Continuance satisfaction & $.417 / .104$ & $1.01 / .285 \star \star$ & $.776 / .206$ \\
Rental stand & - & - & $.877 / .036$ \\
R squared & .078 & .187 & .152 \\
Adjusted R squared & .036 & .162 & .131 \\
Respondents $(n)$ & 136 & 201 & 338 \\
F-value & 1.84 & 7.46 & 7.38 \\
$p$-value & $p<.0001$ & $p<.0001$ & $p<.0001$ \\
\hline Source: $A$ a & & & \\
\hline
\end{tabular}

Source: Authors' analysis

Notes: ${ }^{\star} p<.05 ;{ }^{\star \star} p<.01 ; * \star \star x<.001 ; \hat{p}<.10$

620 Journal of Economic and Financial Sciences / JEF / October 2013 6(3), pp. 611-630 
Null-hypothesis $c$. There is no difference in total education by rental stand operation. According to the analysis of the 2008 data education differs significantly by rental stand operation (TABLE 5). Traders with more education were found to be more likely to operate rental stands only in 2008. Interestingly, in 2008 and in 2010 (TABLES 2 and 4) traders without rental stands are found to earn less if they have less years of education, or alternatively, to earn more if they have more education. This effect is not significant for trades operating rental stands. It is argued that the operation of a rental stand may 'equal out' relative disadvantages of trading in the sector. In other words, the provision of rental stands might 'shield' such traders from the negative influence of the context, which might act along the dimension of dissatisfaction.

TABLE 5: Results of the $t$-tests for differences in Total Education

\begin{tabular}{|c|c|c|c|c|c|}
\hline $\begin{array}{c}\text { Total } \\
\text { Education }\end{array}$ & $\begin{array}{l}\text { Levene's } \\
\text { test Fvalue }\end{array}$ & t-value & $\begin{array}{c}\text { Bootstrapped } \\
\text { Significance } \\
95 \% \text { confidence } \\
\text { levels }\end{array}$ & $\begin{array}{c}\text { Mean for } \\
\text { traders } \\
\text { without rental } \\
\text { stands }\end{array}$ & $\begin{array}{l}\text { Mean for traders } \\
\text { with rental stands }\end{array}$ \\
\hline 2008 & .063 & $-2.1 \star$ & $\begin{array}{l}\text { Lower }-.56 \\
\text { Upper }-.04\end{array}$ & 3.13 (units) & 3.42 (units) \\
\hline 2009 & .35 & -.49 & $\begin{array}{l}\text { Lower }-.70 \\
\text { Upper } .43\end{array}$ & 10.1 (years) & 10.3 (years) \\
\hline 2010 & .995 & -1.25 & $\begin{array}{l}\text { Lower-1.19 } \\
\text { Upper } .304\end{array}$ & 9.7 (years) & 10.2 (years) \\
\hline
\end{tabular}

Source: Authors' analysis

Notes: $* p<.05 ; \star \star p<.01 ; \star \star \star p<.001$.

Null-hypothesis $d$. There is no difference in earnings by rental stand operation.

Traders operating rental stands were found to earn significantly more than traders without rental stands in 2008 and 2009 (TABLE 6).

TABLE 6: Results of the $t$-tests for differences in Gross Earnings per day

\begin{tabular}{lccccc}
\hline Gross Earnings & $\begin{array}{c}\text { Levene's } \\
\text { testFvalue }\end{array}$ & t-value & $\begin{array}{c}\text { Botstrapped } \\
\text { Significance } \\
95 \% \text { confidence } \\
\text { levels }\end{array}$ & $\begin{array}{c}\text { Mean for } \\
\text { traders } \\
\text { without rental } \\
\text { stands }\end{array}$ & $\begin{array}{c}\text { Mean for traders } \\
\text { with rentalstands }\end{array}$ \\
\hline 2008 & $4.1^{*}$ & $-2.1^{*}$ & $\begin{array}{c}\text { Lower }-5.7 \\
\text { Upper }-.016\end{array}$ & $\begin{array}{c}150 \text { (Rand per } \\
\text { day) }\end{array}$ & $\begin{array}{c}178 \text { (Rand per } \\
\text { day) }\end{array}$ \\
2009 & $3.7^{\wedge}$ & $-4.6 * *$ & $\begin{array}{c}\text { Lower }-118.2 \\
\text { Upper }-46.8\end{array}$ & 221 (Rand per \\
day) & 304 (Rand per \\
day)
\end{tabular}

Source: Authors'analysis

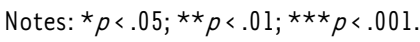


Differences in the structure of predictors of earnings were also found between traders who operate rental stands and those that do not. As indicated, the most significant difference in the structure of associations around earnings according to the standardised regression coefficients is the dominance of Continuance Satisfaction in the regression models of 2008 and 2009 respondents for those traders without rental stands. This result is discussed in the section below that relates to Hypothesis $f$.

In the 2009 data TABLE 3, South African origin is associated with significantly higher earnings only for traders without rental stands. After the xenophobic events of 2008 (Neocosmos, 2008), these results indicate that traders of foreign origin earned significantly less if they did not operate a rental stand. It is argued that the operation of a rental stand might protect traders of foreign origin from certain of the contextual effects that might have constrained their earnings in 2009 .

Another difference is the significance of the gender variable (being male) in the 2010 sample TABLE 2 without rental stands in predicting gross earnings. This result might suggest that the operation of a rental stand might also 'shield' traders from the effects of gender inequality in gross earnings.

The lack of significance of the rental stand item in the regression equations across these three years might suggest that the significant relationship between higher gross earnings (at least for the years 2008 and 2009) acts through other variables that are represented in the equation. It is argued that this result supports the argument that the variables included in the analysis explain most of the positive influence of access to rental stands for such street traders. It is acknowledged that some rental stands might be under the control of individuals who work in the formal sector or who own larger businesses who seek to avoid tax. Further research is recommended in order to investigate this.

Null-hypothesis e. There is no difference in time spent in the sector by rental stand operation.

Traders without rental stands were found to have been in the sector for a shorter period of time, according to the 2009 data. It is tentatively suggested that traders with rental stands might have been less affected by changes that might have driven some traders from the sector subsequent to the 2008 xenophobic events. Further research into the influence of such events on street-trader enterprise behaviour in this context is recommended.

Null-hypothesis $f$ : There is no significant difference in Continuance Satisfaction by rental stand operation.

The bootstrapped $t$-test result was found to be significant at exactly the $p<.05$ level for differences in Continuance Satisfaction by rental stand operation according to the 2009 data. Across the entire sample, no net difference in Continuance Satisfaction by rental stand operation was found. However, when the sample was split between traders with rental stands and traders without rental stands the multiple linear regression results indicated that Continuance Satisfaction was a significant predictor of earnings for traders without rental stands but not those with rental stands. As previously indicated, it is argued that low levels of satisfaction, or relatively high levels of dissatisfaction with continuing in street trading, might constrain the earnings of traders without rental stands. In other words, it is suggested that it might be possible that the operation of a rental stand may 'shield' a trader from the harsh influence of the context, such that dissatisfaction does not cause lower earnings. The alternative explanation might be that more satisfied traders without rental stands earn more. It is plausible to consider that the constraints to the size of rental stands might constrain rental 
stand earnings, while traders who use pavement space might experience a trade-off between larger trading spaces and exposure to by-law infringement. Further research is suggested into the mechanisms that might cause such differences in Continuance Satisfaction for such traders.

Null-hypothesis $g$. There is no difference in age by rental stand operation. According to the analysis of the 2009 data TABLE 7, age is found to be significantly associated with rental stand operation. This association is not found to be significant in the analysis of the 2008 and 2010 data. It is possible that operating a rental stand might have enabled relatively older traders to stay in the sector over this period. It is argued that the influence of the xenophobic violence of 2008 (Neocosmos, 2008) might have influenced relatively older traders to exit the sector if they did not operate rental stands.

TABLE 7: Results of the $t$-tests for differences in Age

\begin{tabular}{|c|c|c|c|c|c|}
\hline Age & $\begin{array}{l}\text { Levene's } \\
\text { test Fvalue }\end{array}$ & t-value & $\begin{array}{c}\text { Bootstrapped } \\
\text { Significance } \\
95 \% \text { confidence } \\
\text { levels }\end{array}$ & $\begin{array}{c}\text { Mean for } \\
\text { traders } \\
\text { without rental } \\
\text { stands }\end{array}$ & $\begin{array}{l}\text { Mean for traders } \\
\text { with rental stands }\end{array}$ \\
\hline 2008 & $3.6^{\wedge}$ & -.069 & $\begin{array}{l}\text { Lower }-2.3 \\
\text { Upper } 1.9\end{array}$ & 32.7 & 32.7 \\
\hline 2009 & $3.3^{\wedge}$ & $-3.4 \star \star$ & $\begin{array}{l}\text { Lower }-5.4 \\
\text { Upper }-1.4^{\star \star}\end{array}$ & 29.7 & 33.2 \\
\hline 2010 & .031 & .278 & $\begin{array}{l}\text { Lower }-2 \\
\text { Upper } 2.7\end{array}$ & 34.3 & 34 (years) \\
\hline
\end{tabular}

Source: Authors'analysis

Notes: ${ }^{*} p<.05 ; * \star p<.01 ; * \star \star p<.001$.

Null-hypothesis $h$. There is no difference in years spent in Johannesburg by rental stand operation. According to the 2008 data, the bootstrapped point biserial correlation between years spent in Johannesburg and the operation of a rental stand was not found to be significant $(-.09 ; p<.109)$ and when age was controlled for the association was also not found to be significant $(-.102 ; p<.061)$. According to the 2009 data, the bootstrapped point biserial correlation was significant $(.213 ; p<.0001)$, and was also found to be significant when the influence of age was controlled for (.134; $p<.019)$. According to the 2010 data, the bootstrapped zero-order point biserial correlation between years spent in Johannesburg and rental stand operation was not found to be significant $(p<.53)$. When partial correlation analysis was used to control for the influence of age, this association was also not found to be significant $(p<.698)$. According to these results, it was only in 2009 that individuals who were found to have spent more time in Johannesburg were found to be more likely to operate rental stands. It is suggested that this association might reflect the positive influence of networks or a significantly greater chance of obtaining a rental stand because of time spent on waiting lists.

Null-hypothesis $i$. There is no significant association between rental stand operation and the capital intensity of product provision. The 2008 data was found to indicate, according to the bootstrapped Pearson chi-squared results (2-sided with 0 cells with an expected count of less than 5; minimum expected count $=22.23$; 1 degree of freedom) of the cross-tabulation tests based upon 1000 iterations, that capital intensity of product provision was significantly 
associated with rental stand operation $(X=11.36 ; p<.001)$. Of traders identified as selling lowcapital-intensive products, $80 \%$ of these traders were found not to operate rental stands. The 2009 data reflected the same pattern, with a Pearson chi-squared value of $6.9(p<.009 ; 2$-sided with 0 cells of an expected count of less than 5 and a minimum expected count of 31.3 ). However, according to the 2010 data, the association was not significant. The null-hypothesis was rejected.

\section{CONCLUSIONS AND RECOMMENDATIONS FOR FURTHER RESEARCH}

The results provide evidence of the positive impact of a 'promotive' state intervention in the informal sector. This research also provides evidence of costs to informal participants associated with such a differentiation that are borne by traders who do not have access to rental stands. It is argued that these results demonstrate that the operation of a rental stand might enable potential capital accumulation in the sector along a range of dimensions. The operation of a rental stand may empower traders to: (i) work more hours a day; (ii) enable female traders to earn more equitable returns in relation to male traders; (iii) enable traders to equal out education-based advantages; and (iv) reduce dissatisfaction with continuance in the sector. If informal sector traders are disadvantaged by their exclusion from the formal sector (Williams and Round, 2010; Cross, 2000), then it is argued that it is the responsibility of appropriate stakeholders to act on the recommendations of research that indicates the specific dimensions along which their conditions of work are inequitable.

It is argued that the operation of a rental stand might allow for capital accumulation through the mechanism of legitimacy, in that such an operation does not leave a street trader vulnerable to by-law infringement (De Soto, 1989). If the operation of a rental stand were indeed a necessary condition for 'graduation' to more capital-intensive levels of informal operations then the provision of such stands might enable the growth of these enterprises. Such growth might also result in growth 'up and out' of the sector itself and into the formal sector (De Soto, 1989). The operation of a local government-vetted rental stand might also yield these higher levels of gross earnings due to the protection afforded to such individuals from contestation for places on the street. It is argued that if in the majority of the years sampled rental stand operation was found to be associated with higher earnings, then certain of the fundamental constraints to the development of enterprise in the sector (De Soto, 1989) might be related to issues related to legitimacy. It is recommended, if the development of these traders is a goal of policymakers, that significantly more local government-endorsed rental stands be erected along more of the street-sides of city and township areas. It is argued that such a step might provide a fundamentally different experience of street trading.

Furthermore, it is also argued that such an action can facilitate capital accumulation in the sector (Callaghan, 2012b). Indeed, the costs associated with not legitimising street traders' enterprise operations might be borne by the most vulnerable in the sector, who might remain trapped, or 'locked out' of the capital-accumulation mechanisms of the sector. It is argued that, should the state intervene by granting large-scale legitimacy to street-trader populations, inner-city street trading and informal street trading in townships can become more of an instrument of development. On the basis of these findings it is argued that higher levels of gross earnings could be possible for street traders should a promotive approach be used. These findings provide some evidence of the efficacy of such an approach, given the already 
acknowledged economic role that the informal sector plays in a society such as South Africa's (Steyn, 2011; Heintz and Valodia, 2008; Simone, 2004).

It is further argued that such an intervention, if applied in an extensive manner, may fundamentally change the nature of the experience of street trading for many in the sector, and facilitate the large-scale upliftment that is possible when the fundamental nature of the sector becomes one of a training ground for entrepreneurship rather than a survivalist 'safety net' for desperate and impoverished people (De Soto, 1989). In relation to other countries over the globe, South Africa has been found to rate very low in entrepreneurial activity, which means that as a source of employment, entrepreneurial activity is underutilised (Ligthelm, 2006). Such an intervention by local governments might, arguably, be necessary in informal-sector streettrading contexts if legitimacy, in the form of such rental stands, is indeed a necessary condition for such people to escape a condition of survivalist enterprise.

In conclusion, it is argued that the provision of more rental stands, and therefore legitimacy, to more of these traders is a 'promotive' intervention that is a logical extension of the development of legislation such as the 1991 Business Act (South Africa, 1991) and the Constitution itself (South Africa, 2012), which places 'upliftment' above 'control' in the economic life of people.

It is already in the spirit of the Constitution to apply promotive policies towards those in our society who are most vulnerable, and that the upliftment of this population of street traders through the provision of rental stands might offer the opportunity to create a 'virtuous circle' of positive externalities that can improve the lives of many.

Further research is recommended, particularly qualitative research that might 'unearth' the nature of potential positive externalities that may accrue to traders who gain access to rental stands. If the experience of street trading is substantively different for those with rental stands, then there might be qualitative benefits for these traders that cannot be captured through empirical testing.

\section{LIST OF REFERENCES}

Adcorp. (2012a). SA labour productivity at the lowest level in 46 years. [Online] Available:

http://www.adcorp.co.za/NEws/Pages/SAlabourproductivityatthelowestlevelin46years.aspx.

(Accessed 26 August 2012)

Adcorp (2011b). Adcorp Employment Index. [Online] Available:

http://www.adcorp.co.za/NEws/Documents/Report\%20Adcorp\%20Employment $\% 20$ Index\%20Septem ber_17-0ct-2011.pdf. (Accessed 26 August 2012)

Becker, G.S. (1964). Human Capital. Chicago: University of Chicago Press.

Bhowmik, S.K. (2005). Street Vendors in Asia: A Review. Economic and Political Weekly, 40(22/23), pp. 2256-2264.

Callaghan, C.W. (2012a). Potential developmental effects of experience in the Southern African inner city street trading sector. African Journal of Business Management, 6(14), pp. 5122-5135.

Callaghan, C.W. (2012b). Financial capital investment effects: the case of the inner city street trading sector. Journal of Economic and Financial Sciences, 5(1), pp. 83-102. 
Calves, A., \& Schoumaker, B. (2004). Deteriorating Economic Context and Changing Patterns of Youth Employment in Urban Burkino Faso: 1980-2000. World Development, 32(8), pp. 1341-1354.

Celik, $\varepsilon$. (2011). The Exclusion of Street Traders from the Benefits of the FIFA World Cup in South Africa. African Journal of Business and Economic Research, 6(1), pp. 62-86.

City of Johannesburg. (2004). Street trading by-laws. [Online] Available: http://www.joburgarchive.co.za/bylaws/streettrading by-laws.pdf. (Accessed 11 January 2011).

Cross, J.C. (2000). Street vendors, modernity and postmodernity: conflict and compromise in the global economy. International Journal of Sociology and Social Policy, 20(1), pp. 29-51.

Crush, J. (1999). Fortress South African and the deconstruction of Apartheid's migration regime. Geoforum, 30(1), pp. 1-11.

Devey, R., Skinner, C. \& Valodia, I. (2006). Definitions, data and the informal economy in South Africa: a critical analysis. In V. Padayachee The Development decade? Economic and Social Change in South Africa, pp. 1994-2004. Pretoria, HSRC Press.

Heintz, J. \& Valodia, I. (2008). Informality in Africa: A Review, paper prepared for SIDA by the WIEGO Network. [Online] Available: http://www.wiego.org/publications/SIDA_regional_reviews. (Accessed 15 July 2011)

International labour Organization. (2002). Decent work and the informal economy. International Labour Organization, Geneva. [Online] Available:

http://www.ilo.org/public/english/standards/relm/ilc/ilc90/pdf/rep-vi.pdf. (Accessed 3 September 2012)

Landau, L. (2007). Discrimination and Development? Immigration, Urbanisation and Sustainable Livelihoods in Johannesburg. Development Southern Africa, 24(1), pp. 67-76.

Ligthelm, A. (2006). An evaluation of the role and potential of the informal economy for employment creation in South Africa. South African Journal of Labour Relations, 30(1), pp. 30-50.

Moser, C. (1978). The Informal Sector or Petty Commodity Production: Dualism or Dependence in Urban Development? World Development, 6(9), pp. 1041-1064.

Neocosmos, M. (2008). The Politics of Fear and the Fear of Politics: Reflections on Xenophobic Violence in South Africa. Journal of Asian and African Studies, 43(6), pp. 586-594.

Nnkya, T. (2006). An Enabling Framework? Governance and Street Trading in Dar es Salaam, Tanzania. A. Brown (ed.) Contested Space: Street Trading, Public Space and Livelihoods in Developing Cities. Warwickshire, Intermediate Technology Publications.

Peberdy, S. (2000). Mobile Entrepreneurship: Informal Sector Cross border Trade and Street Trade in South Africa. Development Southern Africa, 17(2), pp. 201-219.

Peberdy, S. \& Rogerson, C.M. (2003). South Africa: creating new spaces? In: R. Kloosterman and J. Rath (eds). Immigrant Entrepreneurs. Venturing Abroad in the Age of Globalisation, pp. 79-99. New York: Berg.

Pollin, R., Epstein, G., Heintz, J. \& Ndikumana, L. (2006). A employment-targeted economic program for South Africa. United Nations Development Programme. [Online] Available:

http://www.peri.umass.edu/fileadmin/pdf/UNDP_S.Africa.pdf. (Accessed 3 September 2012)

Raveendran, G. (2011). Estimating Domestic Workers, Home-Based Workers, Street Vendors and Waste Pickers in India. [Online] Available at: http://wiego.org/sites/wiego.org/files/publications/. (Accessed 12 April 2012). 
Rogerson, C. (1997). Local economic development and post-apartheid South Africa. Singapore Journal of Tropical Geography, 18, pp. 175-195.

Schoeman, C.H., Botha, I. \& Blaauw, P.F. (2010). Labour Conflict and the Persistence of Macro Underemployment in South Africa. South African Journal of Economic and Management Sciences, 13(3), pp. 272-292.

Shende, S.N. Informal economy. (2002). The special tax regime for small and micro businesses: design and implementation. [Online] Available:

http://unpanl.un.org/intradoc/groups/public/documents/UN/UNPAN006632.pdf (Accessed 10ctober 2013)

Sinha, S., \& Roever, S. (2011). Women in Informal Employment: Globalizing and Organizing. Urban Policies Briefing Note No. 4. [Online] Available: http://wiego.org/sites/wiego.org/files/publications/. (Accessed 12 April 2012)

Skinner, C. (2008). Street Trade in Africa: A Review, Working Paper No.5. [Online] Available: http://wiego.org/sites/wiego.org/files/publications/files/Skinner_WIEGO_WP5.pdf. (Accessed 3 September 2012)

South Africa. (1991). Business Act No.71 of 1991. [Online] Available: http://www.capetown.gov.za/en/CityHealth/Documents/Legislation/Act\%20\%20Businesses\%20Act\%20-\%2071\%20of\%201991.pdf. (Accessed 3 September 2012)

South Africa. (2012). The Constitution of the Republic of South Africa. [Online] Available: http://www.info.gov.za/documents/constitution/1996/a108-96.pdf. (Accessed 3 September 2012) Simone, A. (2004). For the City Yet to Come: Changing African Life in Four Cities. Durham: Duke University Press.

Steyn, I. (2011). Exploring the legal context of informal trade in South Africa.A study commissioned by the Ecumenical Service for Socio-Economic Transformation. Department of Sociology, University of Johannesburg. [Online] Available: http://led.co.za/document/exploring-legal-context-informaltrade-south-africa. (Accessed 3 September 2012)

Streetnet International. (2011). Durban Street traders. [Online] Available: http://wiego.org/sites/wiego.org/files/publications/files/StreetNet_Durban_Street_Traders.pdf. (Accessed 12 April 2012).

Tibaijuka, A. (2005). Report of the Fact-finding Mission to Zimbabwe to Assess the Scope and Impact of Operation Murambatsvina by the UN special envoy on Human Settlements Issues in Zimbabwe. [Online] Available: http://led.co.za/document/exploring-legal-context-informal-trade-southafrica. (Accessed 3 September 2012)

Urban, B. (2006). Entrepreneurship in the Rainbow Nation: Effect of Cultural Values and ESE on Intentions. Journal of Developmental Entrepreneurship, 11(3), pp. 171-186.

Van Rooyen, દ. \& Antonites, A. (2007). Formalising the Informal Sector: A Case Study on the City of Johannesburg. Journal of Public Administration, 42(3), pp. 324-346.

Williams, C.C. \& Round, J. (2007). Entrepreneurship and the informal economy: A study of Ukraine's hidden enterprise culture. Journal of Developmental Entrepreneurship, 12, pp. 119-136. 
Callaghan \& Gwatidzo

\section{APPENDIX}

TABLE Al: Comparative Descriptive Statistics: Means and Frequencies

\begin{tabular}{|c|c|c|c|}
\hline Variables & $2008(n=339)$ & $2009(n=308)$ & $2010(n=303)$ \\
\hline Gender* (Male) & $57 \%$ & $67 \%$ & $62 \%$ \\
\hline Years in Johannesburg & 9.7 & 9.3 & 10.7 \\
\hline Johannesburg origin* & $12 \%$ & $14 \%$ & $8 \%$ \\
\hline Hours worked per day & 10.2 & 10.5 & 10.7 \\
\hline Days worked per week & 6.19 & 6.36 & 6.4 \\
\hline Initial Investment $(R) \star \star ~$ & 428 & 398 & $1181 * \star \star$ \\
\hline Tertiary* & $12 \%$ & $10 \%$ & $15 \%$ \\
\hline Total years of Education & - & 10.17 & 9.9 \\
\hline Experience ${ }^{\star \star}$ (years) & 4.23 & 5.9 & 6.4 \\
\hline Rental Stand* & $41 \%$ & $47 \%$ & $41 \%$ \\
\hline Continuance Satisfaction & $4.28 \star \star \star$ & 8.97 & 6.8 \\
\hline Earnings per day $(R) \star \star ~$ & 161 & 262 & $352 \star \star \star *$ \\
\hline
\end{tabular}

Source: Authors'analysis

Notes: reported values are for means unless the variable is indicated as a binary variable, in which case a percentage is reported: * indicates the percentage of a binary variable; ** indicates upper limit to measure, $\star \star \star$ indicates different upper limit to measure therefore not directly comparable to other data sets.

TABLE A2: Results of the $t$-tests for differences in Initial Investment

\begin{tabular}{|c|c|c|c|c|c|}
\hline $\begin{array}{c}\text { Initial } \\
\text { Investment }\end{array}$ & $\begin{array}{l}\text { Levene's } \\
\text { test Fvalue }\end{array}$ & t-value & $\begin{array}{c}\text { Bootstrapped } \\
\text { Significance } \\
95 \% \text { confidence } \\
\text { levels }\end{array}$ & $\begin{array}{c}\text { Mean for } \\
\text { traders } \\
\text { without rental } \\
\text { stands }\end{array}$ & $\begin{array}{l}\text { Mean for traders } \\
\text { with rental stands }\end{array}$ \\
\hline 2008 & 2.5 & $-4.9 * \star$ & $\begin{array}{c}\text { Lower }-4.4 \\
\text { Upper }-1.8 \star \star\end{array}$ & 7.3 (units) & 10.4 (units) \\
\hline 2009 & $4.4^{\star}$ & $-4.5 \star \star$ & $\begin{array}{c}\text { Upper }-4.6 \\
\text { Lower }-1.8 \star \star\end{array}$ & 6.4 (units) & 9.5 (units) \\
\hline 2010 & $5.99 *$ & $-3.3 *$ & $\begin{array}{l}\text { Lower -822 } \\
\text { Upper -218* }\end{array}$ & 974 (rand) & 1479 (Rand) \\
\hline
\end{tabular}

Source: Authors' analysis

Notes: ${ }^{*} p<.05 ; * \star p<.01 ; * \star \star p<.001$. 
TABLE A3: Results of the $t$-tests for differences in Time in the Sector

\begin{tabular}{|c|c|c|c|c|c|}
\hline Time in sector & $\begin{array}{l}\text { Levene's } \\
\text { test Fvalue }\end{array}$ & t-value & $\begin{array}{c}\text { Bootstrapped } \\
\text { Significance } \\
95 \% \text { confidence } \\
\text { levels }\end{array}$ & $\begin{array}{c}\text { Mean for } \\
\text { traders } \\
\text { without rental } \\
\text { stands }\end{array}$ & $\begin{array}{l}\text { Mean for traders } \\
\text { with rental stands }\end{array}$ \\
\hline 2008 & .88 & .03 & $\begin{array}{l}\text { Lower - } .608 \\
\text { Upper } .693\end{array}$ & 4.2 (years) & 4.2 (years) \\
\hline 2009 & $7.4 * \star$ & $-2.5^{\star}$ & $\begin{array}{l}\text { Lower }-2.96 \\
\text { Upper -.34* }\end{array}$ & 5.1 (years) & 6.7 (years) \\
\hline 2010 & .86 & -.140 & $\begin{array}{l}\text { Lower - } 1.1 \\
\text { Upper } 1.02\end{array}$ & 6.4 (years) & 6.5 (years) \\
\hline
\end{tabular}

Source: Authors' analysis

Notes: ${ }^{\star} p<.05 ;{ }^{*} p<.01 ;{ }^{*}{ }^{\star} p<.001$.

TABLE A4: Results of the $t$-tests for differences in Continuance Satisfaction

\begin{tabular}{|c|c|c|c|c|c|}
\hline & $\begin{array}{l}\text { Levene's } \\
\text { test Fvalue }\end{array}$ & t-value & $\begin{array}{c}\text { Bootstrapped } \\
\text { Significance } \\
95 \% \text { confidence } \\
\text { levels }\end{array}$ & $\begin{array}{c}\text { Mean for } \\
\text { traders } \\
\text { without rental } \\
\text { stands }\end{array}$ & $\begin{array}{l}\text { Mean for traders } \\
\text { with rental stands }\end{array}$ \\
\hline $\begin{array}{l}\text { Continuance } \\
\text { Satisfaction } \\
2008\end{array}$ & .02 & -.26 & $\begin{array}{l}\text { Lower }-.79 \\
\text { Upper } .59\end{array}$ & 4.2 & 4.3 \\
\hline $\begin{array}{l}\text { Continuance } \\
\text { Satisfaction } \\
2009\end{array}$ & $4.0 *$ & $-2.02^{\star}$ & $\begin{array}{l}\text { Lower-1.62 } \\
\text { Upper-.02^ }\end{array}$ & 8.58 & 9.36 \\
\hline $\begin{array}{l}\text { Continuance } \\
\text { Satisfaction } \\
2010\end{array}$ & $6.3 \star$ & -1.9 & $\begin{array}{l}\text { Lower-1.1 } \\
\text { Upper } .03\end{array}$ & 6.53 & 7.11 \\
\hline
\end{tabular}

Source: Authors' analysis

Notes: ${ }^{*} p<.05 ; * \star p<.01 ; * \star \star p<.001$. 
Callaghan \& Gwatidzo 